\title{
Publicaciones del IAPH explora nuevas formas de difusión de sus contenidos: el RAAC, tercer cuaderno digital
}

El Departamento de Publicaciones del IAPH ha culminado la edición de Cien años de arquitectura en Andalucía. El Registro Andaluz de Arquitectura Contemporánea, 1900-2000, publicación digital que el usuario puede descargarse de forma gratuita desde la web del Instituto. Es el tercer cuaderno de la colección de libros electrónicos (e-ph cuadernos), reciente apuesta y reto editorial por su potencial como recurso para explorar nuevas formas de difusión de contenidos. Para esta ocasión, también se ha realizado una edición limitada del cuaderno en formato CD.

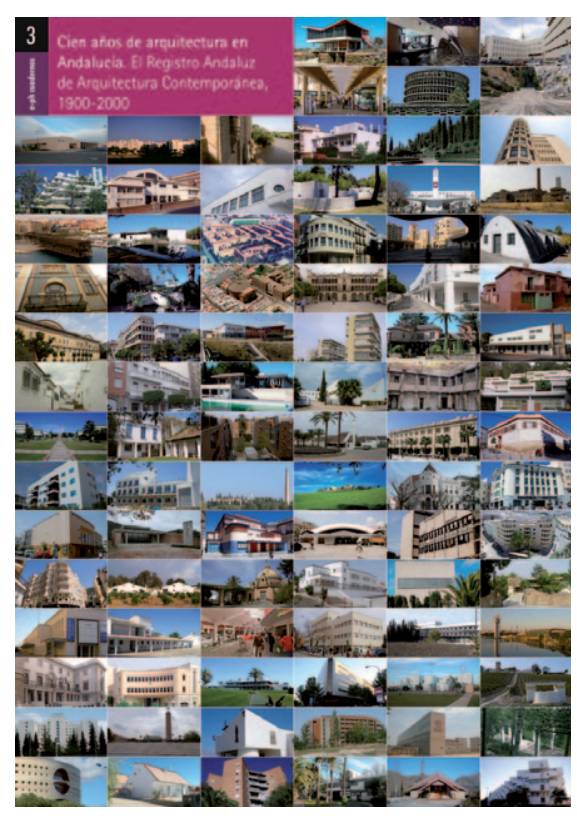

Portada del e-ph cuadernos $n .{ }^{\circ} 3$, descargable en la web del IAPH

La arquitectura y el urbanismo del siglo XX siguen siendo cuestiones patrimoniales pendientes, que se enfrentan al desafío de una ajustada ponderación de sus valores históricos, culturales, sociales y tecnológicos, que requiere de una cuidada atención. Arquitecturas y ciudades en las que se ha desarrollado la vida y el trabajo de las generaciones más pobladas y geográficamente móviles de la historia, que son parte indisoluble de la cultura contemporánea, al mismo nivel que sus tradiciones.

La implicación del IAPH en la identificación del patrimonio arquitectónico y urbano del siglo XX ha sido constante desde sus orígenes, a través de su vinculación a Docomomo y a la realización de proyectos específicos de la arquitectura contemporánea del siglo $X_{\text {, entre }}$ los que destaca el registro y publicación MoMo Andalucía (1999), que incluyó un total de 64 bienes representativos de la arquitectura del movimiento moderno en nuestra comunidad.

Continuando esta labor, la realización del Registro Andaluz de Arquitectura Contemporánea (RAAC) constituye un nuevo hito, tanto por su extensión, al incorporar más de 1.100 registros de la arquitectura del siglo XX en Andalucía, como por su ambición, al promoverse su protección efectiva a través de la inclusión de su contenido en el Inventario de Bienes Reconocidos del Patrimonio Histórico de Andalucia y el Catálogo General de Patrimonio Histórico Andaluz.

Tras la conclusión del RAAC, su difusión ha ido encaminada a mejorar su conocimiento y puesta en valor, así como a una mejor apreciación de la producción arquitectónica en Andalucía en un contexto nacional y europeo. Esta tarea, que se ha desarrollado a través de la realización de productos específicos como la Base de Datos de Arquitectura Contemporánea de Andalucía y el desarrollo de rutas culturales, se completa con la realización de la publicación electrónica Cien años de arquitectura en Andalucía. El Registro Andaluz de Arquitectura Contemporánea, 1900-2000 que ahora se presenta.

En ella se ofrece una sintesis del trabajo realizado, desde su metodología hasta sus contenidos, situando este estudio dentro de un panorama general de reconocimiento de los valores de la arquitectura contemporánea. El grupo de expertos vinculados a la realización del RAAC desarrolla en sus páginas una revisión del estado de la cuestión en cada una de las ocho provincias, que apunta tanto hacia los hitos conseguidos como a las posibles lineas de desarrollo de trabajos futuros.

\section{La implicación del IAPH en la identificación del patrimonio arquitectónico y urbano del s. XX ha sido constante}

De interés también resultan las aportaciones realizadas por expertos externos, que hacen una valoración crítica de la arquitectura y las ciudades andaluzas a lo largo del siglo $X X$, así como de los agentes vinculados a su producción, los paisajes que generaron y las posibilidades de reciclaje que en su natural obsolescencia se ofrecen.

De manera tan sencilla como siguiendo la ruta de acceso www.iaph.es/web/canales/ publicaciones/cuadernos/eph-cuadernos/ contenido/ePH_Cuaderno3, los lectores encontrarán en este compendio de textos una referencia en el estudio de nuestro pasado más reciente, en el que se ha procurado un especial rigor, que corresponda a su trascendencia en el entendimiento de nuestro presente y su proyección hacia el futuro.

\section{Plácido González Martínez}

Arquitecto colaborador del Centro de Documentación y Estudios del IAPH 